Proc. Estonian Acad. Sci. Geol., 2005, 54, 3, 181-190

\title{
Thelodont Oeselia mosaica gen. et sp. nov. from the Wenlock and Ludlow of the East Baltic
}

\author{
Tiiu Märss \\ Institute of Geology at Tallinn University of Technology, Estonia pst. 7, 10143 Tallinn, Estonia; \\ Tiiu.Marss@gi.ee \\ Received 5 April 2005, in revised form 20 May 2005

\begin{abstract}
A thelodont Oeselia mosaica gen. et sp. nov. is described from the Upper Wenlock and Lower Ludlow (Silurian) of Estonia and Latvia. The species has very small to small scales and shows low variation in scale morphology, simple branching dentine tubules, and a specific ultrasculpture with polygons of irregular shape, separated by narrow grooves.
\end{abstract}

Key words: Thelodonti, Agnatha, Silurian, East Baltic.

\section{INTRODUCTION}

The entire East Baltic Silurian sequence from the Upper Llandovery to the Prridoli contains thelodont scales of variable size, with rhomboidal, seemingly smooth crown surface and a relatively high neck. In microstructure the scales are rather similar to those of Thelodus parvidens. As the sculpture of the crown is lacking, the identification of these scales is very difficult. Larger scales, appearing in the upper Ludlow and continuing into the Prridoli, were first described by L. Agassiz (see Murchison 1839) as Thelodus parvidens from the Welsh Borderland in Britain. Very small scales from the Llandovery and/or Wenlock, Lower Silurian, have also been considered as T. parvidens (Turner 1973, 2000; Turner \& Nowlan 1995), Thelodus sp. cf. T. parvidens (Turner 2000), Thelodus sp. (Märss 1982, 1986; Fredholm 1990; Talimaa 2000; Märss \& Miller 2004), or Thelodus sp. n. 1 (Karatajūtè-Talimaa \& Brazauskas 1995). On the basis of specific microstructure, lack of sculpture on the crown main surface, and presence of a relatively high neck, similar very small to small scales from the Samoilovich and Ust' Spokoinaya formations (Wenlock and Ludlow) of October Revolution Island, Severnaya Zemlya 
Archipelago, have been identified as T. calvus (Märss \& Karatajūtè-Talimaa 2002). Another taxon, T. inauditus Märss, Wilson \& Thorsteinsson, with a smooth, domelike crown and very distinct scale neck, but with an anteriorly displaced base and microstructure different from that of T. calvus and T. parvidens, has been described from the Cape Phillips Formation (Lower Wenlock) on Cornwallis Island, Canadian Arctic Archipelago (Märss et al. 2002).

In the Wenlock part of the southern British succession, single scales of Thelodus sp. occur sporadically throughout the series and up into the Pridoli (Märss \& Miller 2004). The scales were identified as Thelodus sp. as they had morphological features typical of this genus but no distinct features allowing their identification to species level. The scales are very small to small, mushroomshaped, without any visible sculpture on the crown surface but with a relatively high neck that occasionally carries vertical ridgelets. The base lies anteriorly of the scale and is low, with a pulp opening in its centre. Thin sections from this material showed Thelodus-type histology. Märss \& Miller (2004) suggested that the material from the Llandovery, Wenlock, and Lower Ludlow of the Welsh Borderland could belong to one or more new taxa rather than to T. parvidens. They also thought that these very small scales (or denticles) might be derived from some area, for example from the branchial region of Loganellia, the most widespread taxon in the Llandovery.

When describing thelodonts, Gross (1967) mentioned two types of fine patterns: the "netzartiges Muster" on the surface of very fine scales and "feine Schrägstreifung" on the surface of larger scales of the thelodont Thelodus laevis (= T. schmidti) (Pander). The patterns were not illustrated because they were too fine to be recorded by the light microscope. We know today (Märss accepted) that Gross actually described the striation occurring on the scales of Thelodus laevis (Pander) and the fine network-like pattern of the scales of a taxon which is treated in more detail herein. On the basis of the ultrasculpture of the crown surface Märss (ibid.) subdivided thelodonts into five high rank groups, with the scales with a polygonal pattern forming one group. Below, the new taxon is formally established based on the features of the finest pattern on the scale crown surface. This is the first time that ultrasculpture has been used for that purpose.

The scales of this new taxon can be reliably identified when studied under the scanning electron microscope only. At the same time this is impossible when dealing with thousands of scales; the procedure is too time-consuming and expensive. With experience, it is possible to obtain rather good results with the light microscope. Setting the scale under a low angle towards the light, one can observe a different, iridescent shine caused by the ultrasculpture. Because the ultrasculpture occurring on the crown of mushroom-shaped scales has not been documented so far, a complete synonymy list cannot be given.

The described scale collection is housed in the Institute of Geology at Tallinn University of Technology under the registration numbers GIT 346 and GIT $431+$ scale number. 


\title{
SYSTEMATIC DESCRIPTION
}

\author{
Class AGNATHA Cope, 1889 \\ Subclass THELODONTI Kiaer, 1932 \\ INCERTI ORDINIS \\ Family OESELIIDAE nov.
}

Type genus. Oeselia gen. nov.

Diagnosis. Thelodonti with scale crown carrying irregular polygonal pattern of ultrasculpture.

Content. Oeselia gen. nov. only.

Stratigraphical range. Wenlock and Lower Ludlow, middle part of the Silurian.

Remark. In the future, the feature given in the diagnosis might serve as a basis for the diagnosis of order level (Märss accepted).

Genus Oeselia gen. nov.

Derivation of name. From Oesel, the old name for Saaremaa Island, Estonia.

Type species. Oeselia mosaica gen. et sp. nov.

Diagnosis. As for type species.

Oeselia mosaica gen. et sp. nov.

Plate I, figures 1-18; Plate II, figures 1-6

2001 Thelodonti gen. et sp. nov.; Nestor et al., fig. 5

accepted Oeselia mosaica Märss; Märss, figs. 3, 11R

Derivation of name. Latin mosaica, in reference to polygonal ultrasculpture pattern on the scale crown surface.

Holotype. GIT 431-69; P1. I, fig. 9.

Type locality and horizon. Sample at a depth of 36.60-36.65 m, Kipi core, Saaremaa Island, Estonia; Vesiku Beds, Rootsiküla Stage, Upper Wenlock, Lower Silurian.

Material. Hundreds of scales with ultrasculpture documented on the crown surface. Vesiku-507 core, depth 3.20-3.40 m, and Vesiku outcrop; Kipi core, depth 36.60-36.65 m; Kuressaare (= Kingissepa) core, depth 51.84-51.92 m; Riksu-803 core, depth 60.0-64.8 m; Tehumardi core, depth 68.0-68.1 m; Viita and Vesiku beds of the Rootsiküla Stage, Homerian, Upper Wenlock, Lower Silurian; Saaremaa, Estonia; Ventspils core, depth 615.8-616.0 m, Latvia; Šešupe Beds of the Dubysa Formation, Lower Ludlow, Upper Silurian. Most of the Šešupe Beds of the Dubysa Formation are absent in the Silurian sections of Estonia (Nestor 1995). 
PLATE I
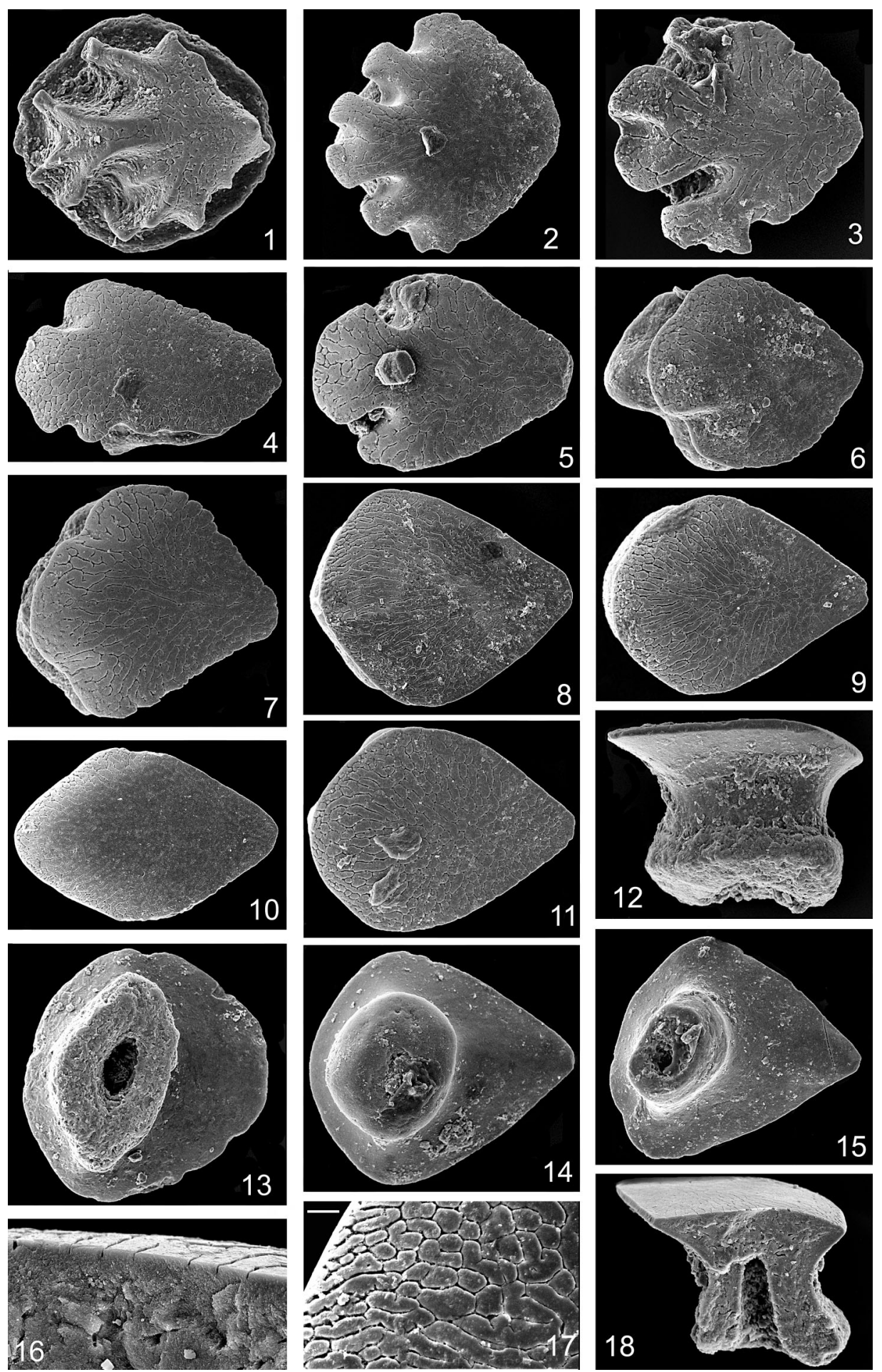
Diagnosis. Morphological variation of scales low; scales very small to small (0.20-0.45 mm long), with flat or anteriorly lowering surface; neck narrow; base smaller than crown, often stretched laterally; sculpture, if present, distributed only anteriorly of scales; ultrasculpture of irregular polygonal fields separated by narrow grooves; crown of simple, branching fine dentine tubules.

\section{Description}

Morphology. Only three morphological varieties of the scales were documented: head, transitional, and trunk scales. The head scales (Pl. I, fig. 1) have a deeply crenulated crown and indistinct neck between the crown and the base. The perimeters of the base are not quite as extensive as those of the crown. The base is situated mid-scale, as is the pulp opening. The transitional scales (Pl. I, figs. 27) have notches either anteriorly (Pl. I, figs. 2, 3) or, if the scales are more elongate, antero-laterally of the crown (Pl. I, figs. 4-7). The neck is distinct, observed as a constriction between the crown and the base. The base, situated to the anterior of the scale, can mirror the configuration of the crown having small notches antero-laterally, but usually it is oval or rhomboidal. In more elongate transitional scales the crown protrudes over the base posteriorly. The trunk scales (Pl. I, figs. 8-18) have usually a quadrangular crown surface, with a tapering posterior part, flat or lowering to the anterior. The neck is distinctly constricted (Pl. I, figs. 12, 18; Pl. II, figs. 2, 4). The base is situated anteriorly of the scale; it is smaller than the crown, sometimes very small (Pl. I, fig. 15). The configuration of the base is rhomboidal (Pl. II, fig. 6), elliptical (Pl. I, fig. 13; Pl. II, fig. 5) or roundish (Pl. I, fig. 14). The lateral corners of the base are often turned to the anterior (Pl. II, figs. 1, 3). Mostly the base is smooth but sometimes the surface of the base is somewhat nodular (Pl. I, fig. 13).

The surface of the scales, which appears flat and smooth under the light microscope, reveals the ultrasculpture of a fine pattern of irregular polygons or

\section{Explanation of Plate I}

Oeselia mosaica gen. et sp. nov. Morphology and ultrasculpture of the scales. 1, head scale; $2-7$, transitional scales; $8-18$, trunk scales. $1-11$, scales in crown view; 12 , a scale in postero-lateral view; 13-15, trunk scales in base view; 16, 18, trunk scales in vertical cross-section; 17, ultrasculpture of the crown. 1, 4, 6, 7, 11, 12, 15, 17, Vesiku-507 core, depth 3.2-3.4 m; 2, 3, 5, 9, 14, Kipi core, depth 36.60-36.65 m; 8, 16, 18, Vesiku Brook; 13, Tehumardi core, depth 68.0 $68.1 \mathrm{~m}$; Saaremaa Island, Estonia; Vesiku Beds of the Rootsiküla Stage, Wenlock, Lower Silurian; 10, Ventspils core, depth 615.8-616.0 m, Latvia; Šešupe Beds of the Dubysa Formation, Lower Ludlow, Upper Silurian.

1, GIT 431-54, $\times 195 ; 2$, GIT 431-64, ×175; 3, GIT 431-63, ×190; 4, GIT 431-57, ×110; 5, GIT 431-65, $\times 155 ; 6$, GIT 431-56, $\times 150 ; 7$, GIT 431-55, $\times 155 ; 8$, GIT 346-17, $\times 145 ; 9$, holotype, GIT 431-69, $\times 145 ; 10$, GIT $431-80, \times 110 ; 11$, GIT 431-60, $\times 155 ; 12$, GIT 431-62, $\times 195 ; 13$, GIT 431-83, $\times 130$; 14 , GIT $431-66, \times 155 ; 15$, GIT 431-58, $\times 140 ; 16$, GIT $431-100$, length of the figure $60 \mu \mathrm{m}$; 17, GIT 346-17, scale bar $10 \mu \mathrm{m}$; 18, GIT 431-101, $\times 140$. 
PLATE II

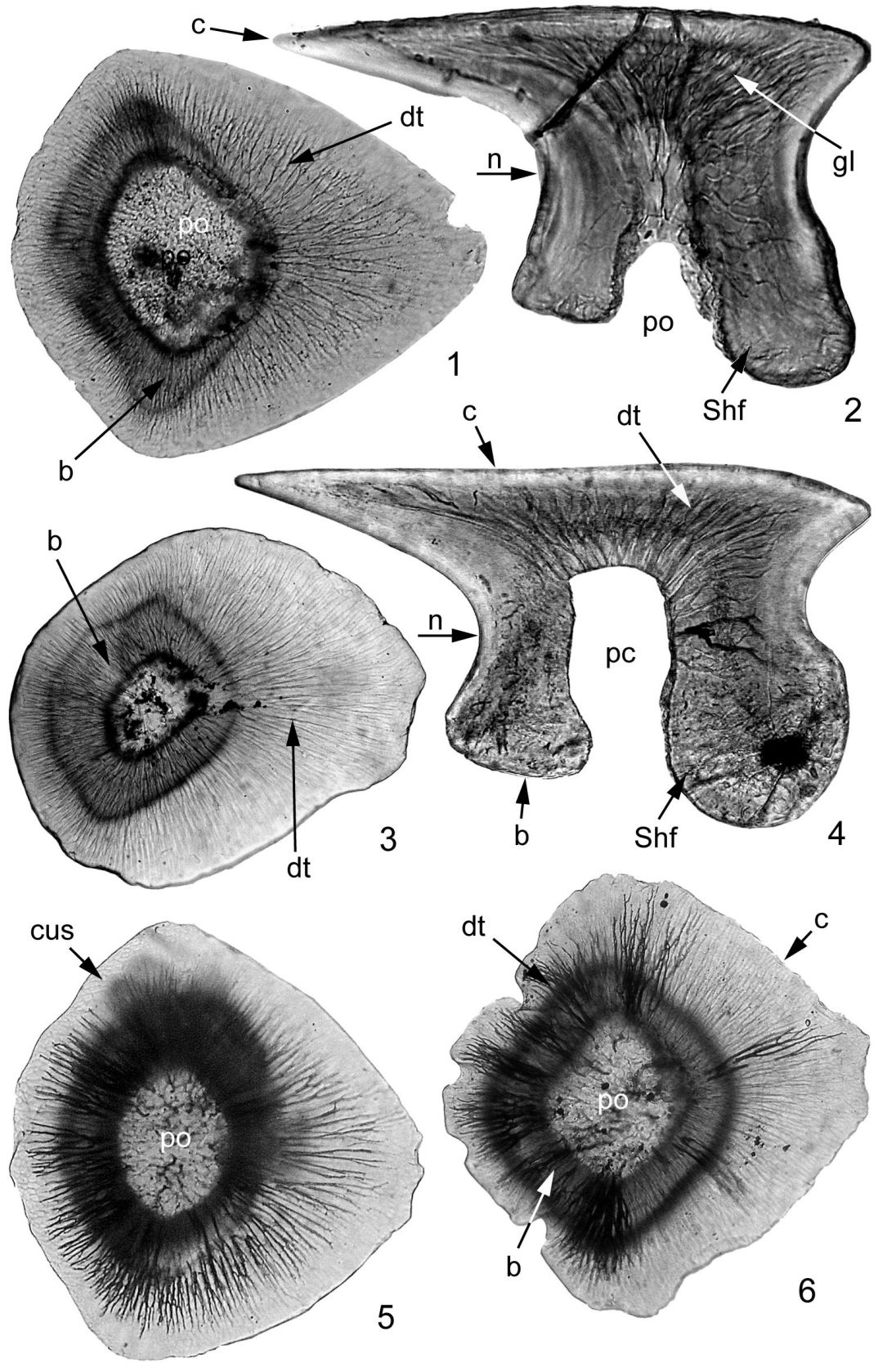


polygonal fields (Pl. I, figs. 1-11, 17). The ultrasculpture is distributed over the entire scale surface. The polygons are of very irregular shape, often curvy or kidney-shaped. More regular polygons occur at the margins of the crown, while along the midline of the crown the polygons are elongate and run anteroposteriorly. Polygons, ca. $5 \mu \mathrm{m}$ in width, are separated by very narrow grooves about $1.5 \mu \mathrm{m}$ wide. This pattern occurs in the uppermost hypermineralized tissue (Pl. I, figs. 16, 18).

Histology. The crown of the scales is built of dentine (Pl. II, figs. 1-6), while the uppermost layer of the scales is of more compact enameloid tissue (Pl. I, fig. 16). The dentine tubules are fine, tightly spaced, and relatively straight on the scale in horizontal view (Pl. II, figs. 1, 3, 5,6) but more sinuous in the middle part of the crown in vertical cross-section of the scale. Tubules branch on 3-5 levels (Pl. II, figs. 2, 4) which correspond to 3-5 growth lines (Pl. II, fig. 2). Sometimes the growth lines are indistinct (Pl. II, fig. 4). In Pl. II, figs. 1, 3, 5, 6, the pattern of dentine tubules occurs in the centre of the scale (seen through the pulp opening) as a complicated network of loops. The loops seem to be coarser and are not tied with the network of the ultrasculpture (Pl. II, fig. 5). In the neck, the dentine tubules are sparse and more irregularly distributed (Pl. II, figs. 2, 4). Tubules of Sharpey's fibres are weakly developed (Pl. II, figs. 2, 4).

Remarks. Apart from true Thelodus parvidens Agassiz from the Upper Ludlow and Prridoli of the Baltic and Britain, scales in gross morphology superficially resembling $T$. parvidens, are known from the Silurian of some regions of the northern hemisphere. Thelodus macintoshi Stetson, found near Nerepis, New Brunswick, eastern Canada, is thought to be closely related if not identical to Thelodus parvidens Agassiz (Turner 1986). Thelodus macintoshi scales are large, up to $1.5 \mathrm{~mm}$ long, with a well-developed base and numerous vertical ridgelets on the neck. Turner (1986) also included in this taxon T. bicostatus and T. trilobatus scales from the same localities. Such a set of scales is, indeed, very similar to T. parvidens. There is some confusion about the locality and age, which was suggested to be as old as late Llandovery or as young as early Přidoli. As a result, further study is needed before synonymizing these two taxa. Another taxon, T. calvus Märss \& Karatajūtè-Talimaa also has very small to small scales (width and height $0.4 \mathrm{~mm}$ ). The scales differ as they are without any sculpture on the

\section{Explanation of Plate II}

Oeselia mosaica gen. et sp. nov. Microstructure of the scales. 1, 3, 5, 6, scales in horizontal section; 2 , 4, scales in vertical longitudinal section. 1, 5, Ruhnu-500 core, depth 307.0-307.15 m, Ruhnu Island; 2, 3, 6, Ruhnu-500 core, depth 291.65-291.80 m; 4, Vesiku Brook, Saaremaa Island, Estonia; Vesiku Beds of the Rootsiküla Stage, Wenlock, Lower Silurian.

Abbreviations: b, base; c, crown; cus, crown ultrasculpture; $\mathrm{dt}$, dentine tubules; gl, growth layer; n, neck; pc, pulp cavity; po, pulp opening; Shf, tubules for Sharpey's fibres.

1, GIT 431-112, ×235; 2, GIT 431-106, ×360; 3, GIT 431-108, ×130; 4, GIT 431-110, ×310;

5, GIT 431-111, ×230; 6, GIT 431-109, ×180. 
crown main surface, have a very distinct, rather high neck, and a base placed at the anterior of the scale. They also have a complicated pulp cavity with openings of dentine canals, dentine canals in the base, neck, and lower part of the crown, and dentine tubules arising from dentine canals and forming bunches upwards. In specific microstructure T. calvus scales differ from other Thelodus species as well as from Oeselia mosaica gen. et sp. nov. Thelodus inauditus Märss, Wilson \& Thorsteinsson has small scales (length $0.4-0.6 \mathrm{~mm}$, width $0.4-0.5 \mathrm{~mm}$ ), a smooth, dome-like crown and a very distinct scale neck without vertical ridgelets, and an anteriorly displaced base. Dentine tubules varying in shape from straight and fine to rather wide in the lower part of the crown differ from those in T. calvus and T. parvidens.

Five ultrasculpture types, and a smooth condition of the surface have also been documented (Märss accepted): (1) fine striation on Thelodontiformes, Shieliiformes, Phlebolepidiformes, and Barlowodidae, (2) wavy transverse lamellae on Furcacaudiformes, (3) irregular polygons on Oeselia, (4) irregular micronodules, and (5) short v-shaped slits, both on the scales of yet undescribed Canadian thelodonts. A smooth crown surface, not having any finest pattern, characterizes the scales of Sandiviiformes and Loganelliiformes.

Ultrasculpture has been revealed on the scales of a few Thelodus species only: T. parvidens (bands separated by narrow grooves just anteriorly on the crown), and $T$. laevis and $T$. carinatus (fine striation). So far, no ultrasculpture has been found on the smooth scale crowns of T. macintoshi, T. inauditus, and T. calvus. In the new taxon the ultrasculpture consists of polygonal fields separated by narrow grooves over the whole crown. The polygonal ultrasculpture has also been described on the true scales of a chondrichthyan Kannathalepis milleri (in Märss \& Gagnier 2001, figs. 3H-I) and putative chondrichthyan Frigorilepis caldwelli (Märss et al. 2006). The doubt that these scales might be the bucco-pharyngeal denticles of Loganellia cannot be confirmed because the scales from the squamation and denticles of the bucco-pharyngeal area should have the same type of ultrasculpture. Namely, recently it was found that bucco-pharyngeal denticles of Phlebolepis elegans Pander were covered with the same type of ultrasculpture of fine longitudinal striation as the scales of the squamation (unpublished data by M. Wilson and T. Märss). Because of different ultrasculpture of other thelodont scales, Oeselia gen. nov. must be treated as a separate genus.

As a conclusion, the significance of the ultrasculpture in the study of the scales is stressed to stimulate palaeoichthyologists to look for it. Beside the morphological and histological features, the ultrasculpture is the third important character to identify taxa from the scattered scale material.

\section{ACKNOWLEDGEMENTS}

This study was supported by research grant No. 0331760s01 (holder D. Kaljo, Tallinn), and grants Nos. 5726 and 5920 of the Estonian Science Foundation. 
H. Perens and A. Põldvere, Geological Survey of Estonia, provided the core samples. SEM pictures were taken by V. Mikli in the Centre for Material Research at Tallinn University of Technology. Images of thin sections were taken and both plates improved by G. Baranov. The help of all the above mentioned people and institutions is gratefully acknowledged. I also thank the referees, E. Kurik (Tallinn), G. Miller (London), and V. Talimaa (Vilnius) for their comments.

\section{REFERENCES}

Cope, E. D. 1889. Synopsis of the families of Vertebrata. Amer. Naturalist, 23, 849-887.

Fredholm, D. 1990. Agnathan vertebrates in the Lower Silurian of Gotland, Sweden. Geol. Fören. Stockholm Förh., 112, 61-84.

Gross, W. 1967. Über Thelodontier-Schuppen. Palaeontographica, 127, Abt. A, 1-67.

Karatajūtè-Talimaa, V. \& Brazauskas, A. 1995. Distribution of vertebrates in the Silurian of Lithuania. Geologija, 17, 106-114.

Kiaer, J. 1932. New coelolepids from the upper Silurian of Oesel (Estonia). Publ. Geol. Inst. Tartu Univ., 27, 1-8.

Märss, T. 1982. Vertebrate zones in the East Baltic Silurian. In Ecostratigraphy of the East Baltic Silurian (Kaljo, D. \& Klaamann, E., eds.), pp. 97-106. Valgus, Tallinn.

Märss, T. 1986. Silurian vertebrates of Estonia and West Latvia. Fossilia Baltica, Vol. 1. Valgus, Tallinn (in Russian with extended English summary).

Märss, T. Exoskeleton ultrasculpture of early agnathans and fishes. J. Vertebr. Paleontol. (accepted).

Märss, T. \& Gagnier, P.-Y. 2001. A new chondrichthyan from the Wenlock, Lower Silurian, of Baillie-Hamilton Island, the Canadian Arctic. J. Vertebr. Paleontol., 21, 693-701.

Märss, T. \& Karatajūtè-Talimaa, V. 2002. Ordovician and Lower Silurian thelodonts from Severnaya Zemlya Archipelago (Russia). Geodiversitas, 24, 381-404.

Märss, T. \& Miller, C. G. 2004. Thelodonts and distribution of associated conodonts from the Llandovery-lowermost Lochkovian of the Welsh Borderland. Palaeontology, 47, 12111266.

Märss, T., Wilson, M. V. H. \& Thorsteinsson, R. 2002. New thelodont (Agnatha) and possible chondrichthyan (Gnathostomata) taxa established in the Silurian and Lower Devonian of the Canadian Arctic Archipelago. Proc. Estonian Acad. Sci. Geol., 51, 88-120.

Märss, T., Wilson, M. V. H. \& Thorsteinsson, R. 2006. Silurian and Lower Devonian thelodonts and putative chondrichthyans from the Canadian Arctic Archipelago (Cornwallis, BaillieHamilton, Devon, and Prince of Wales Islands). Spec. Pap. Palaeontol., 75 (in press).

Murchison, R. I. 1839. The Silurian System. Murray, London.

Nestor, H. 1995. Comments on the modernised Silurian correlation chart of Estonia and Latvia. Geologija, 17, 88-95.

Nestor, H., Einasto, R., Nestor, V., Märss, T. \& Viira, V. 2001. Description of the type section, cyclicity, and correlation of the Riksu Formation (Wenlock, Estonia). Proc. Estonian Acad. Sci. Geol., 50, 149-173.

Talimaa, V. 2000. Significance of thelodonts (Agnatha) in correlation of the Upper Ordovician to Lower Devonian of the northern part of Eurasia. In Palaeozoic Vertebrate Biochronology and Global Marine/Non-Marine Correlation. Final Report of IGCP 328 (1991-1996) (Blieck, A. \& Turner, S., eds.), Cour. Forschungsinst. Senckenberg, 223, 69-80.

Turner, S. 1973. Siluro-Devonian thelodonts from the Welsh Borderland. J. Geol. Soc. London, 129, 557-584.

Turner, S. 1986. Thelodus macintoshi Stetson 1928, the largest known thelodont (Agnatha: Thelodonti). Breviora, 486, 1-18. 
Turner, S. 2000. New Llandovery to early Přídolí microvertebrates including Lower Silurian zone fossil, Loganellia avonia nov. sp., from Britain. In Palaeozoic Vertebrate Biochronology and Global Marine/Non-Marine correlation. Final Report of IGCP 328 (1991-1996) (Blieck, A. \& Turner, S., eds.), Cour. Forschungsinst. Senckenberg, 223, 91-127.

Turner, S. \& Nowlan, G. S. 1995. Early Silurian microvertebrates of eastern Canada. Bull. Mus. Nat. Hist. Natur., Paris, 17, 513-529.

\section{Telodont Oeselia mosaica gen. et sp. nov. Baltikumi Wenlockist ja Ludlow'st}

\section{Tiiu Märss}

Uus telodont Oeselia mosaica gen. et sp. nov. on kirjeldatud Eesti ja Läti Siluri Ülem-Wenlocki ja Alam-Ludlow' kihtidest. Seda taksonit iseloomustavad väikesed, 0,2-0,45 $\mathrm{mm}$ pikad, väikese morfoloogilise varieeruvusega soomused, mille dentiinkude koosneb lihtsatest dihhotoomsetest dentiinikanalikestest. Krooni pealispinna ultraskulptuuris joonistuvad välja ebakorrapärased polügonid, mis on üksteisest eraldatud kitsaste vaokestega. 